\title{
Psikobiyolojik Kişilik Kuramı Faktörleri İle İş Performansı Arasındaki İlişkide Etik Eğilimlerin Etkisi

\author{
(The Effect of Ethical Tendencies on the Relationship Between Psychobiological
} \\ Personality Theory Factors and Job Performance)
}

\author{
Ahmet DOĞAN iD a , Tayfun ARAR iD b , Melehat ÖNEREN iD c, Cihat KARTAL iD d \\ aKırıkkale Üniversitesi, Kırıkkale, Türkiye. ahmet@ahmetdoganca.com \\ bKırıkkale Üniversitesi, Kırıkkale, Türkiye. tayfunarar@kku.edu.tr \\ cKırıkkale Üniversitesi, Kırıkkale, Türkiye. melahatonerenn@gmail.com \\ dKırıkkale Üniversitesi, Kırıkkale, Türkiye. dr_cihat_kartal@yahoo.com
}

\begin{tabular}{|c|c|}
\hline MAKALE BİLGİSİ & ÖZET \\
\hline $\begin{array}{l}\text { Anahtar Kelimeler: } \\
\text { Kişilik } \\
\text { İş Performansı } \\
\text { Etik Eğilimler } \\
\text { Karakter } \\
\text { Mizaç } \\
\text { Gönderilme Tarihi } 6 \text { Temmuz } \\
2019 \\
\text { Revizyon Tarihi } 17 \text { Eylül } 2019 \\
\text { Kabul Tarihi } 20 \text { Eylül } 2019\end{array}$ & 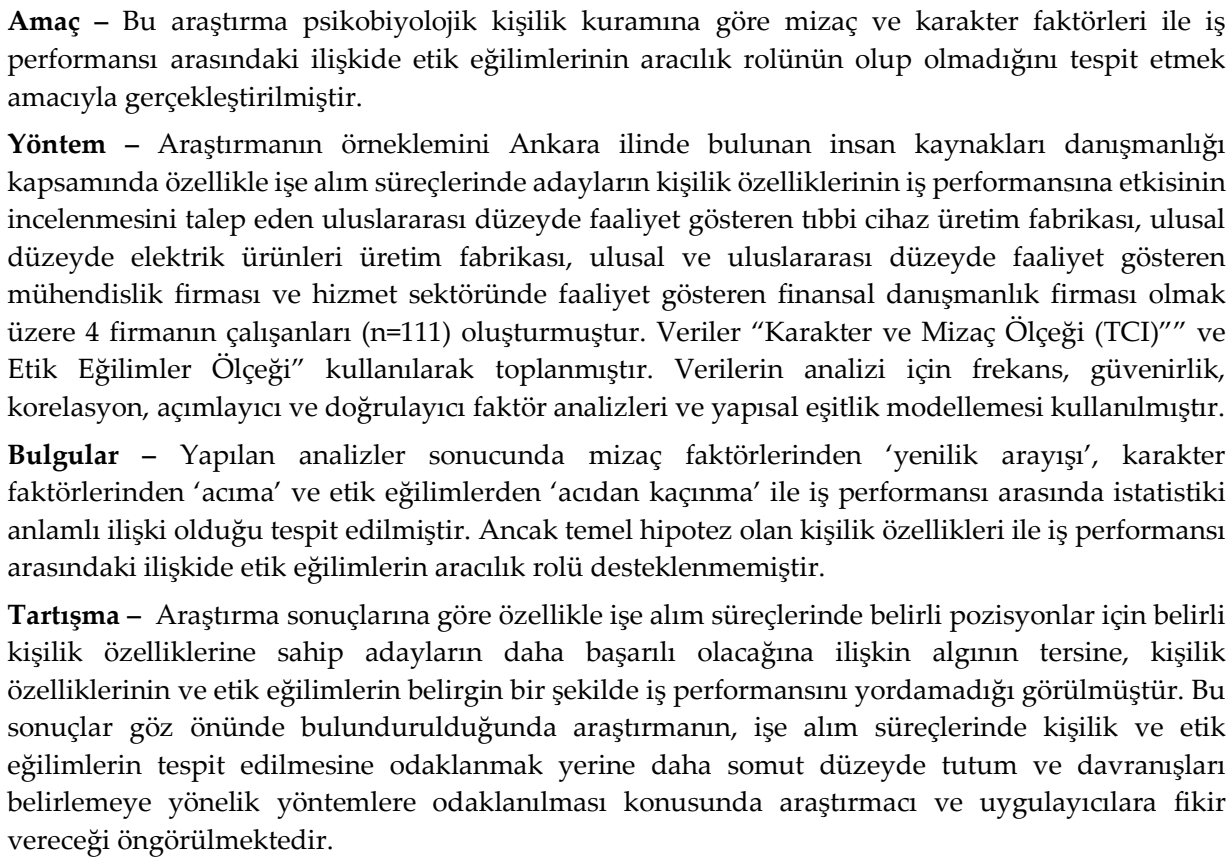 \\
\hline
\end{tabular}

\begin{tabular}{|c|c|}
\hline ARTICLE INFO & ABSTRACT \\
\hline Keywords: & Purpose - This study was carried out in order to determine whether ethical tendencies mediate the \\
\hline Personality & $\begin{array}{l}\text { relationship between temperament and character factors and job performance according to } \\
\text { psychobiological personality theory. }\end{array}$ \\
\hline Ethical Tendencies & Design/methodology/approach - Within the scope of human resources consultancy in Ankara \\
\hline Character & province, the sample of the study consisted of the employees of 4 firms $(n=111)$ in Ankara, which \\
\hline Temperament & $\begin{array}{l}\text { is an internationally operating medical device manufacturing factory, a national electrical products } \\
\text { manufacturing factory, a national and international engineering firm and a financial consultancy }\end{array}$ \\
\hline Received 6 July 2019 & firm operating in the service sector which demand the examination of the effect of personality traits \\
\hline Revised 17 September 2019 & on job performance in recruitment processes. Data were collected using the "Character and \\
\hline Accepted 20 September 2019 & $\begin{array}{l}\text { Temperament Scale (TCI)" and Ethical Tendencies Scale ". Frequency, reliability, correlation, } \\
\text { exploratory and confirmatory factor analyzes and structural equation modeling were used for data }\end{array}$ \\
\hline Article Classification: & \\
\hline Research Article & $\begin{array}{l}\text { Findings - As a result of the analyzes, it was found that there was a statistically significant } \\
\text { relationship between 'seeking novelty' as one of the temperament factors, 'pity' as one of the } \\
\text { character factors and 'pain avoidance' as one of the ethical tendencies and job performance. } \\
\text { However, the basic hypothesis which investigates the mediation role of ethical tendencies in the } \\
\text { relationship between personality traits and job performance was not supported. }\end{array}$ \\
\hline
\end{tabular}




\begin{abstract}
Discussion - According to the results of the study, contrary to the perception that candidates with certain personality traits will be more successful especially for certain positions in recruitment processes, it is seen that personality traits and ethical tendencies do not predict job performance significantly. When these results are taken into consideration, it is predicted that the research will give an opinion to researchers and practitioners to focus on methods to determine attitudes and behaviors at a more concrete level rather than focusing on identifying personality and ethical tendencies in recruitment processes.
\end{abstract}

\title{
1. GİRIŞ
}

Elton Mayo ve çalışma arkadaşları örgütlerdeki insan ilişkilerinin önemini ortaya koydukları çalışmaları ile 1920'li yılların sonlarına doğru yeni bir yönetim anlayışının temelini atmıştır. Bu çalışmaların ardından, insanı tanıma, anlama, yönetme ve işletmelerin verimliliğini artırma amacıyla yapılan çalışmalar sayesinde işletme, sosyal psikoloji, psikoloji alanlarında oldukça önemli gelişmeler sağlanmıştır. Elektronik ticaret, sermaye ve emeğin artan hareketliliği, bilgiye ulaşmanın görece olarak kolaylaşması gibi pek çok etmen işletme yönetiminde önemli değişimlerin yaşanmasına neden olmuştur. Söz konusu değişimlerin sonucunda işletme yönetimi anlayışında meydana gelen gelişmelerin odak noktasında insan unsurunun yer aldığı (Aykaç, 1999: 4) görülmektedir. Örgütler tarafından istihdam edilen insanların, becerileri, tutum ve davranışları, ilişki kurma ve yönetme tarzları, inanç ve değerleri örgütlerin başarısını belirleyen en önemli unsurlar arasında değerlendirilmektedir. Örgütlerin başarısında etkili bir kaynak olmakla birlikte insan, her bireyin bir diğerinden farklı olması, fiziksel, zihinsel ve duygusal boyutlarıyla tam olarak anlaşılmasına ilişkin sorunlar nedeniyle yönetilmesi en zor olan kaynaklar arasındadır. Ancak bu zor kaynağın etkin yönetilmesiyle de örgütlerin ulaşabileceği başarı beklentilerin çok üzerine çıkmaktadır (Barutçugil, 2004: 11). İnsan kaynağının nasıl yönetileceği, büyük ölçüde o insanın nasıl ve ne şekilde anlaşıldığına bağlıdır; bu bakımdan insanları anlamak, bireysel, mesleki veya sosyal ilişkilerin temelinde bulunan zorunluluklardan biri olarak görülmektedir. Örgütsel başarıyı sağlamak için insan kaynağının etkinliğini artırmayı amaçlayan yönetici ve liderler, insan hakkında ne kadar çok şey öğrenirse insanlarla o kadar iyi başa çıkılabilecektir (Eysenck ve Wilson, 2000: 41). Bu kapsamda örgütlerin başarısında kritik bir önem taşıyan insanların kişilik ve iş performansı arasındaki ilişki geçen yüzyıl içerisinde endüstriyel psikoloji içinde sıklıkla araştırılan konulardan biri olmuştur. Barrick, Mount ve Judge (2001: 9-10) tarafından yapılan meta analiz çalışmasında, kişilik ve performans arasındaki ilişkiyi araştıran çalışmalar incelendiğinde bu çalışmaların genel olarak iki fazda toplanabileceği, 1980'lerin ortalarına kadar olan ve birinci faz olarak adlandırdıkları dönemde kişilik ve performans arasında sıfıra yakın korelasyon olduğuna ilişkin sonuçların bulunduğu, 1980'lerin ortalarından 2001 yılına kadar ağırlıklı olarak 5 faktörlü kişilik modeliyle iş performansı arasındaki ilişkinin incelendiği ikinci faz dönemde ise önceki döneme göre kişilik ve performans arasında daha anlamlı ilişkilerin bulunduğu belirtilmiştir.

İş etiği, Protestan etik anlayışı, İslami iş etiği gibi farklı etik anlayış ve değerleri ile iş performans arasındaki ilişkiyi inceleyen araştırmalarda, Protestan etik anlayışına sahip kişilerin daha fazla çalıştığı ve daha fazla çıktı ürettiği (Merrens ve Garrett, 1975; Greenberg, 1977), İslami etik eğiliminin çalışan performansını önemli ölçüde etkilediği (Marri vd., 2012), güçlü iş etiğinin mükemmel iş performansını sağladığı (Ntayi, 2005; Osibanjo vd., 2015) belirtilmektedir. Çalışanların kişilikleriyle birlikte etik değerleri de birçok sonucun önemli belirleyicileri olarak hizmet eden önemli psikolojik özellikler arasında yer alır. Ancak genelde kişilik özellikleri ve değerler sık sık ayrı ayrı incelenerek, ilişkileri sınırlı bir şekilde anlaşılmaktadır (Parks-Leduc vd., 2015: 3). Kişilik, etik ve iş performansı ile ilgili olarak literatür incelendiğinde 1990'lardan itibaren yapılan araştırmaların daha çok beş faktörlü kişilik modeli ve iş performansı arasındaki ilişkileri incelediği ancak iş performansı ile kişiliğin mizaç ve karakter boyutları arasındaki ilişkilere değinilmediği görülmüştür. Etik eğilimlerle iş performansı arasındaki ilişkilerle ilgili olarak Imam vd.'nin 2013 ve 2015 yıllarında yaptıkları X ve Y Kişilik modellerinde İslam iş etiğinin işçi performansına etkisi çalışmalarında olduğu gibi belirli etik değerler, kişilik tipleri ile iş performansı arasındaki ilişkilerin incelendiği, etik eğilimlerle iş performansı arasındaki ilişkilerin incelenmediği tespit edilmiştir. Bunlarla birlikte mizaç ve karakter faktörlerinin iş performansı üzerindeki etkisinde felsefi etik eğilimlerinin aracılık rolü olup olmadığına ilişkin çalışmalara rastlanılmamıştır. Bu çalışma kapsamında Psikobiyolojik Kişilik Kuramı bağlamında karakter ve mizaç faktörleri ile iş performansı arasındaki ilişkide etik eğilimlerin aracılık rolü incelenmiştir. 
A. Doğan - T. Arar - M. Öneren - C. Kartal 11/3 (2019) 2273-2289

\section{KAVRAMSAL ÇERÇEVE}

\subsection{Kişilik Kavramı ve Psikobiyolojik Kişilik Kuramı}

Kişilik kavramının çıkış noktası "insan” dır. Bu nedenle kişi ve kişiliği tanımlamadan önce bir kavram olarak insanın tanımlanması gerekir. "İnsan nedir?" sorusuna biyologlar, psikologlar, eğitimciler, işletmeciler, antropologlar, sosyologlar, hekimler gibi farklı bilim alanlarıyla ilgilenen uzmanlar tarafindan ilgilendikleri bilimin uğraşı çerçevesinde farklı şekilde cevaplar verilecektir. Ülkemizde felsefi antropolojinin kurucularından olan Takiyettin Mengüşoğlu insanı, bilen, yapıp-eden, değerlerin sesini duyan, tavır takınan, önceden gören ve önceden belirleyen, isteyen, özgür hareketleri olan, tarihsel olan, ideleştiren, kendisini bir şeye veren, seven, çalışan, eğiten ve eğitilen, devlet kuran, inanan, sanat ve tekniğin yaratıcısı olan, konuşan, biyopsişik bir yapıya sahip olan bir varlık olarak ifade eder (Mengüşoğlu, 1988: 13). Spranger'e (2001: 12) göre insan, ancak yeryüzündeki psişik organizmalar arasında çok biçimli bir fenomen ve büyük çeşitlilik imkanları taşıyan biyolojik bir varlık olarak yorumlanmak suretiyle bütünüyle anlaşılabilir. Bunun doğal bir sonucu olarak insanın farklılı̆̆ı sadece biyolojik faktörlere değil, zihni ve kültürel faktörlere de bağlıdır.

Biyolojik bir varlık olarak insanın kişi olabilmesi Max Scheler'e göre, insan varoluşunun ancak belirli bir basamağında meydana gelebilir, kişi kavramı ancak bu basamak üzerine kurulabilir, kişi olmak belli bir insan tipini gerektirir. Kişi olmak için insanda birtakım özellikler ve niteliklerin bulunması gerekir (Akarsu, 1998: 93; Scheler 2015, 117-118).

Her ne kadar psikoloji bilimi içinde kişilik psikolojisi ancak 1930'lu yıllarda diğer sosyal bilim alanlarından ayrı bir bilimsel disiplin olarak ortaya çıkmaya başlamış (Soysal, 2008: 6; Cloninger, 2009:3) olsa da kişilik kavramı insanın 'kendini bilme ve diğer insanları anlama çabasının' doğal bir sonucu olarak yüzyıllar boyunca ilgi duyulan, üzerinde düşünülen bir kavramdır.

Kişilik, kişinin davranışının bütün detayları ile en uygun şekilde kavramsallaştııılması (McClelland, 1951: 23) kişinin olduğu ve olmaya çalıştığı her şey (Menninger, 1953: 23) şeklinde de oldukça kapsamlı bir biçimde tanımlanabilir. Bir başka ifade ile kişilik, kişinin kendine göre bir ayrılı̆̆ının, belirgin özelliklerinin olması durumudur, kişinin 'kendine özgü'lüklerinin bir bileşimi (Köroğlu ve Bayraktar, 2007: 3; Cohen ve Swerdlik, 2015: 379) şeklinde de tanımlanabilmektedir. Fromm kişiliği (1995: 24) bir bireye özgü olan ve bireyi eşsiz kılan, doğuştan getirilmiş ve sonradan kazanılmış tinsel niteliklerin tümü olarak ifade eder.

Özetle bir kişinin davranışındaki zaman ve durumlar karşısındaki tutarlığını ve aynı durumda insanlar arasındaki davranışsal farklılıkları açıklamak için kullanılan kişilik, tutarlı davranış özellikleri grubunda bireyin eşsizliğine işaret eden (Weiten vd., 2015: 33) bir kavramdır.

Psikobiyolojik modelde kişilik, kişinin değişen çevreye uyumunu sağlayan psikobiyolojik sistemlerin dinamik organizasyonu şeklinde tanımlamış olup biyolojik olarak belirlenmiş mizaç ve kişiliğin sonradan edinilmiş karakter boyutları olmak üzere temel iki bileşenden oluşmaktadır (Cloninger vd., 1993: 975-977). Psikobiyolojik kişilik teorisi, mizacın faktörünün temelini ve sonradan edinilen karakterin gelişmesini açıklayarak kişiliğin ikisi arasındaki etkileşimin son ürünü olduğunu öne sürmektedir (Köse, 2003: 86).

Cloninger'in teorisi, öğrenme modeli ile genetik (insan, hayvan ve evrim çalışmaları), psikoloji (öğrenme teorisi, bilişsel psikoloji, kişilik kuramları, psikofizyoloji) ve psikiyatri (psikofarmakoloji, nozoloji, uzunlamasına araştırmalar) dahil olmak üzere birçok alanda bilgilerin birleşmesi sonucu nörobiyolojik temelli bir öğrenme modeli olarak ortaya çıkmıştır (Yalçın, 2017: 10). Bu teori, kişiliğin tüm yaşam süresi boyunca sosyal, çevresel ve genetik etkiler arasındaki etkileşimle belirlendiğini varsayar (Ricther ve Neumann, 2011: 249). Teoriye göre, genetik olarak düzenlenmiş nörofizyolojik süreçler, davranışı aktive etme, sürdürme ya da engelleme eğilimlerini yönlendiren ve belirli bir toplumdaki menfaat, düşünce ve inançların edinimini etkileyen temel kişilik boyutlarını belirler. Psikobiyolojik kişilik kuramı kapsamında mizaç özellikleri, birbirinden genetik olarak bağımsız, yaşamın erken dönemlerinde şekillenen, kişiliğin biyolojik temelini oluşturmaktadır (Cloninger vd., 1991: 1048).

Cloninger vd,'e (1993: 980) göre kişiliğin kalıtımsal tarafını oluşturan Mizaç, bireyin yaşamı boyunca durağan ve kültürel etkiler nedeniyle değişmeyen özellikleri kapsamaktadır. Aynı çalışmaya göre bu özelliklerin farklı kültür, kıta, etnik grup ve politik sistemlere rağmen evrensel nitelikte olduğu ifade edilmiştir. 


\section{A. Doğan - T. Arar - M. Öneren - C. Kartal 11/3 (2019) 2273-2289}

Daha çok psikososyal etmenlerden etkilenen karakter, öz-kavramlarda bireysel bir farklılık olarak tanımlanır ve yaşam süresi boyunca sosyalleşme süreçleri tarafından ağırlıklı olarak saptanan kişiliğin ikinci alanını temsil eder, gönüllü hedefler ve değerlerdeki bireysel farklılıklara karşılık gelir (Arkar, 2008: 116). Psikobiyolojik kuramda karakter genetik yapının dört mizaç boyutunun onaylanmasının ardından kişiliğin özbildirim veya gözlemci değerlendirmesiyle tanımlanmaya çalışılan ve mizaç ile ilişkili olmayan boyutlar olarak tanımlanmıştır.

\section{2. İş Performansı}

İşletme yönetimi, insan kaynakları yönetimi, endüstriyel ve örgüt psikolojisi gibi birçok alanın en temel konularından biri olan iş performansının pek çok tanımı vardır. İşletmelerdeki en önemli konulardan biri çalışanların işlerini, o iş için tanımlanan kriter ve standartlara ne ölçüde uygun olarak gerçekleştirdiğidir. Bu noktandan hareketle genel olarak iş performansını, çalışanların örgütsel amaçlarla bağlantılı olarak bu hedeflere nasıl katkıda bulunduğunu gösteren ölçeklenebilir eylem, davranış ve sonuçlar (Viswesvaran ve Ones, 2002: 216) şeklinde tanımlamak mümkündür. Benzer şekilde iş performansı denetmenler veya örgütsel liderler tarafından yapılan değerlendirmeye göre çalışanın kuruluştaki genel değeri olarak (Chamberlin vd., 2018: 3) da ifade edilebilir.

Performans değerlendirmeleri, daha önce belirlenmiş standartlara göre çalışanın performansının ölçülmesi anlamına gelir ki buradan elde edilen bilgi ve veriler, bireysel olarak çalışanın kendisi, amiri ve tüm kuruluşun amaçları için kullanılabilir. Performans değerlendirme, çalışanlar için, kariyerinde ilerleme, ücret artışları, zayıflıkların fark edilmesi, iş amaçlarının oluşturulması için bilgi sunar. Gözetmen ve yöneticiler için, terfi, alt seviyeye indirme, ücret artışı, işten çıkarma, yapıcı eleştiricide bulunma imkanı sağlar. Amir ve çalışan arasında iletişimi güçlendirir. Örgütler için performans değerlendirme, çalışanın ve biriminin verimliliğinin değerlendirilmesidir (Riggio, 2013: 129-130).

Bireyin yeteneği ve motivasyonun beklenilen performans düzeyine erişmede büyük öneme sahip iki etmendir, yetenekleri aynı olsa bile farklı motivasyon seviyelerine göre bireyler farklı düzeylerde performans sergileyebilmektedir (Özkan ve Omay 2019, 745).

İş performansının çok boyutlu bir yapısı olduğu geniş ölçüde kabul görmekte olup, bağlamsal performans ve görev performansı yaygin olarak kabul edilen iki boyuttur (Befort ve Hattrup 2003, 17). Görev performans1 bir üründe üretim yapmak, mal satma, envanter alma, astları yönetme veya hizmet sunma gibi bir işin yerine getirilmesindeki temel sorumlulukları ifade eder. Bağlam performansı ise ilave iş için gönüllü olmak, işe coşkuyla devam etmek, başkalarıyla iş birliği yapmak, örgütü desteklemek ve savunmak gibi davranış, tutumlarla kendini gösteren örgütün sosyal ve psikolojik ortamına katkı sağlamayı ifade eden performans boyutudur (Çankır ve Arıkan 2019, 1137).

İş performansı temelde örgütün misyonuna ulaşmak amacıyla gerçekleştirilen davranışlardan hangilerinin örgütün başarısı için daha değerli olduğunun belirlenmesi esasına dayandığından görev ve bağlamsal

performansın genel performans üzerindeki ağırlıklarının bilinmesi insan kaynakları yönetimi açısından önemli faktörler olarak görülmektedir (Özer ve Özdoğan 2019, 1211).

\subsection{Etik Eğilim}

İnsanca yaşayabilmenin olmazsa olmaz bir koşulu (Kuçuradi, 2009: 47) olarak ifade edilen etik, insanların davranışlarını kendilerine göre düzenlediği bir ilkeler sistemi ya da dizisi (Türkeri, 2013: 11) olarak tanımlanabilir. Etik, hangi davranışın doğru ya da yanlış olduğunu tanımlar (Osibanjo vd., 2015: 108). Bireyin, diğer bireyler, kurumlar ve devlet ile olan ilişkilerinde toplumun deneyimlerinden, gelenek ve göreneklerinden kaynaklanan, akıl ürünü olan, toplumsal uyuşum, birliktelik ve dayanışmayı artııcı, dolayısıyla toplumun ekonomik, politik ve sosyal yapılarına istikrar sağlayıcı prensiplerin, standartların ve değerlerin bir bütünü olarak (Kolçak, 2013: 3) tanımlanan etik yaşamın her alanında olduğu gibi işletmeler için de büyük bir önem taşımaktadır.

Genel olarak insan düşünce ve davranışının bir özelliği (Öhman ve Östman 2008, 59) şeklinde tanımlanan etik eğilimler, bireylerin ahlaki değer yargıları taşıyan konulardaki karaları ve gerçekleştireceklerdeki eylemlerde önem kazanmaktadır. Bir eylemi doğru ya da yanlış olarak değerlendirebilmek konusunda çerçeveyi belirleyen aynı zamanda karşıt ve karmaşık durumları çözümleyebilmek için bir karara ulaşmayı destekleyen 


\section{A. Doğan - T. Arar - M. Öneren - C. Kartal 11/3 (2019) 2273-2289}

etik eğilimler, bireylerin bir olay karşısında farklı bakış açılarına sahip olmalarına (Alakavuklar ve Arbak 2008, 703) ve farklı davranmalarına neden olurlar. Etik eğilimler pratikte, değer yargılarının metafiziksel düzlemdeki karşılıklarına ilişkin değerlendirmeler değil aksine belirli eylemleri doğru ya da yanlış şeklinde iletmenin antropolojik bir değerlendirmesidir (Öhman ve Östman 2008, 61-62).

Çalışanlar ve yöneticiler çalışma yaşamında her gün etik sorunlarla karşılaşabilmektedir. Ayrıca karar alma süreçlerinde etik unsurlarla yüzleşmenin yanı sıra, liderlik sorumlulukları yerine getirilirken de etik konularla karşılaşılır (Carroll, 1999: 141). Çalışan davranışları ve sınırlı kaynak dağıtımı gibi çeşitli nedenlerle ortaya çıkan etik sorunlarla yöneticiler sıklıkla karşılaşmaktadır. Bu noktada etik ile ilgili problemlere yönelik çözümlerin nitelikle birlikte bireysel ve örgütsel gibi çeşitli performans düzeylerine doğrudan etkisi önem arz etmektedir (Nelson, 2005: 9).

\section{YÖNTEM}

İşletmelerin başarılı olabilmeleri için, çalışanların işletmenin belirlenen amaç ve hedeflerine ulaşmaya katkı sağlamak konusunda istekli olması ve bu doğrultuda bireysel yetenek ve becerilerini kullanarak işletme yönetimine destek olmaları beklenir. Çalışanların işletme tarafından belirlenen hedeflere ulaşma sürecindeki katkılarının bir göstergesi olarak da tanımlanabilecek iş performansında, çalışanların psikobiyolojik kuramda belirtilen kişilik özellikleri ve etik eğilimlerinin etkisi araştırılmıştır.

Yapılan literatür taramasında kişilik özellikleri ve iş performansı arasındaki ilişkiyi araştıran pek çok çalışma olduğu görülmüş olup, bu çalışmaların önemli bir çoğunluğu 5 faktör kişilik kuramı ile iş performansı arasındaki ilişkiyi incelemektedir (Barrick vd., 2001; Rothmann ve Coetzer, 2003; Tett ve Burnett, 2003; Yelboğa 2006; Soysal 2008; Şeker, 2011; Imam vd., 2015; Hui-Hua ve Schutte, 2015; Callen vd., 2018; Stajkovic vd., 2018).

Cloninger'in psikobiyolojik modelinin alt faktörleri ve beş faktör kişilik boyutlarının eş değerlilikleri ile ilgili yapılan çalışmalarda beş faktör kişilik boyutları ile TCI (Temperament and Character Inventory) ölçek boyutlarının önemli ölçüde örtüştügü (De Fruyt vd., 2000: 441), TCI envanterinin yenilenmiş beş faktör envanterinin alanlarının yordayıcısı olarak 0.54 ile 0,80 arasında çoklu korelasyon olduğu (MacDonald ve Holland, 2002: 921) bulunmuştur. Bu çalışmada hem beş faktör kişilik envanteriyle büyük ölçüde örtüşmesi hem de kişiliği beş faktörlü kişilik modelinden farklı olarak temelde mizaç ve karakter boyutları ile ele alması nedeniyle TCI ölçeği kullanılmıştır. Bu sayede çalışan performansının yordayıcısı olarak kişiliğin daha çok kalıtsal ve biyolojik boyutu olan mizaç boyutları ile kişiliğin sonradan edinilmiş karakter boyutları arasında farklılık olup olmadığını incelemek mümkün olacaktır. Bu çalışmada Psikobiyolojik Kişilik Kuramı kapsaminda,

- $\quad$ Karakter ve mizaç faktör ve alt faktörleri iş performansının anlamlı bir yordayıcısı mıdır?

- $\quad$ Karakter ve mizaç faktör ve alt faktörleri etik eğilimlerinin anlamlı bir yordayıcısı mıdır?

- $\quad$ Etik eğilimleri iş performansının anlamlı bir yordayıcısı mıdır?

sorularına cevap aranmıştır.

\subsection{Araştırmanın Modeli}

Kişilik özellikleri örgütsel davranışı etkilediği gibi örgütsel performansı da etkilemektedir (Raja vd., 2004: 351; Şeker, 2011: 79). Kişiliğin aynı zamanda ölçülebilir boyutlarının iş performansının öngörülmesinde de kullanılabileceği Tett ve Burnett in (2003: 300) ve Callen vd.'nin (2018: 38) çalışmalarında ifade edilmektedir. Bu çalışmada Imam vd. (2015) ile Tett ve Burnett (2003) tarafından yapılan çalışmalarda kullanılan modellerden hareketle Şekil 1'de yer alan model oluşturulmuştur.

Parks-Leduc vd. tarafından değerler ve kişilik arasındaki ilişkileri inceleyen 60 çalışma üzerinde yapılan meta analizde bilişsel kişilik özellikleriyle etik değerler arasında kuvvetli ilişki, duygusal özelliklerle daha zayıf ilişki olduğu (2015: 3) ifade edilmektedir. Kişilik özelliklerinin etik davranış üzerindeki etkilerini inceleyen çalışmalarda bulunan beş faktörlü kişilik özelliklerinden dışa dönüklük hariç diğer kişilik özelliklerinin etik davranışı yordayacak istatistiki olarak anlamlı ilişki (Anwar ve Shah, 2018: 105-106) olduğu bulunmuştur.

Tüm insan davranışlarında olduğu gibi çalışanların iş performansında da bireyin sahip olduğu kişisel özellikleri, etik anlayışları ve içerisinde bulunduğu durum önemli etmenlerdir. Buna göre kişilik özellikleri iş performansını etkileyen bağımsız değişken, etik eğilimler kişilik özelliklerinin iş performansı etkisinde ara değişken ve çalışanların bireysel iş performansları ise bağımlı değişken olarak tanımlanmıştır. 
Bağımsız Değişken

Kişilik Özellikleri
Ara Değişken

Etik Eğilimler
Bağımlı Değişken

Bireysel İş Performansı

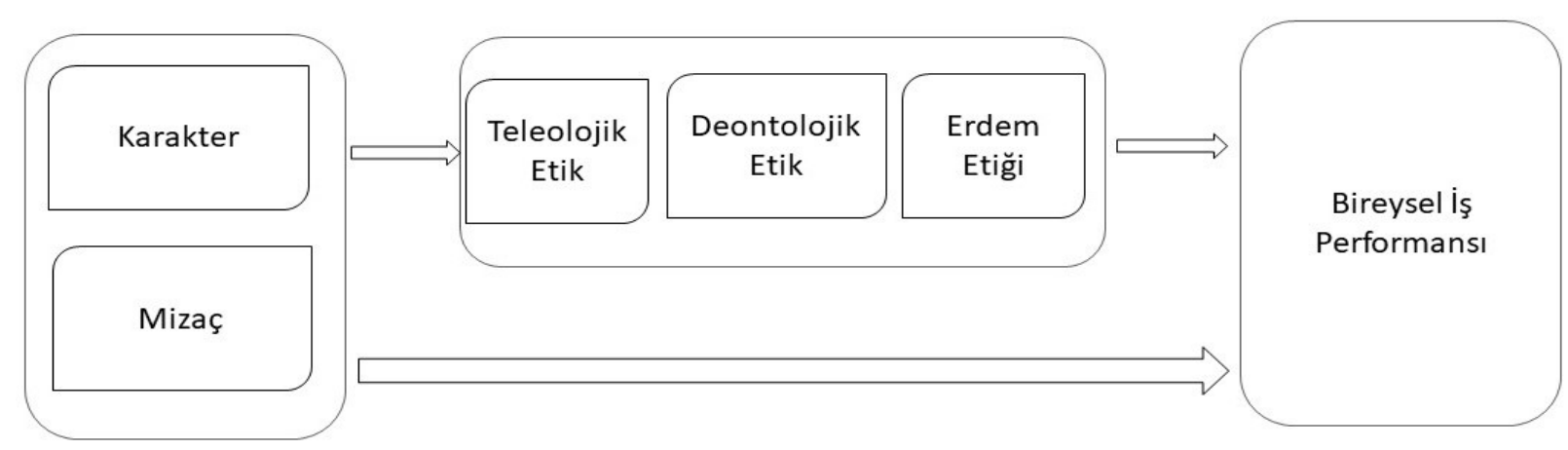

Şekil 1. Araştırma Modeli

\subsection{Araştırmanın Hipotezleri}

Özellikle 1990'lı yıllardan itibaren yapılan meta analiz çalışmaları kişiliğin iş performansı için anlamlı bir öncül olduğuna yönelik (Hogan ve Holland, 2003: 100) bulgular ve TCI ölçeği ile Beş Faktör envanter boyutlarının örtüşmesine ilişkin (De Fruyt vd., 2000: 441) araştırmalar göz önünde bulundurulduğunda, TCI ölçeğinin alt boyutları ile iş performansı arasında anlamlı bir ilişki olması beklenmektedir. Bu bilgiler ışı̆̆ında araştırmada ilk iki hipotez aşağıdaki şekilde ifade edilmiştir.

$\mathrm{H}_{1}$ : Mizaç faktörleri ve iş performansı arasında anlamlı bir ilişki vardır.

$\mathrm{H}_{2}$ : Karakter faktörleri ile iş performansı arasında anlamlı bir ilişki vardır.

Beş faktörlü kişilik özellikleri ile etik değerleri arasında sürekli ve anlamlı bir ilişki (Parks-Leduc vd., 2015: 3) göz önünde bulundurulduğunda, karakter ve mizaç faktörleri ile etik eğilimleri arasında anlamlı bir ilişki olması beklenmektedir. Bu nedenle araştırmada yer alan üçüncü ve dördüncü hipotezler aşağıdaki şekilde ifade edilmiştir.

$\mathrm{H}_{3}$ : Karakter faktörleri ile etik eğilimleri arasında anlamlı bir ilişki vardır.

$\mathrm{H}_{4}$ : Mizaç faktörleri ile etik eğilimleri arasında anlamlı bir ilişki vardır.

Farklı etik anlayışların ve değerlerin işçi performansına etkisine yönelik çalışmalar (Greenberg, 1977; Imam vd., 2015) göz önünde bulundurulduğunda, etik değerler ile iş performansı arasında anlamlı bir ilişki olması beklenmektedir. Bu bağlamda beşinci ve altıncı hipotezler aşağıdaki şekilde ifade edilmiştir.

H5: Etik eğilimler ile iş performansı arasında anlamlı bir ilişki vardır.

H6: Kişilik özellikleri ile iş performansı arasındaki ilişkide etik eğilimlerin aracılık rolü vardır.

\subsection{Veri Toplama Araçları}

Araştırmada kullanılacak veriler ölçekler aracıllğıyla doğrudan çalışanlardan alınan veriler (kişilik özellikleri ve etik eğilimler) ve işletmeden alınan (çalışanların yıllık performans değerlendirme sonuçları) olmak üzere temelde iki farklı kaynaktan sağlanmıştır.

Psikobiyolojik Kuram kapsamında kişiliğin değerlendirilmesi için TCI (Temperament and Character Inventory - Mizaç ve Karakter Envanteri) kullanılmıştır. Özellikle son yıllarda dünya çapında araştırmacılar tarafından kullanım sıklığı oldukça artmış bu envanter, kişinin kendisinin doğru/yanlış şeklinde soruları yanıtladığ Cloninger'in kuramıyla bağlantılı olarak, dört mizaç (zarardan kaçınma, ödül bağımlılığı, sebat etme ve yenilik arayışı) ve üç karakter (kendini aşma, kendini yönetme ve iş birliği yapma) boyutunun ışığında oluşturulmuştur. 


\section{A. Doğan - T. Arar - M. Öneren - C. Kartal 11/3 (2019) 2273-2289}

Psikobiyolojik modele göre, genetik olarak birbirinden bağımsız, yaşam boyunca durağan ve kültürel etkiler karşısında değişmez oldukları varsayılan mizaç, dört boyuttan [yenilik arayışı (YA), zarardan kaçınma (ZK), ödül bağımlılığı (ÖB) ve sebat etme (S)] ve tecrübeyle şekillenen, sosyo-kültürel öğrenmeyle vücut bulan, yetişkinlikte olgunlaştıkları varsayılan karakter ise üç boyuttan [kendini yönetme (KY), iş birliği yapma (İ) ve kendini aşma (KA)] oluşmaktadır (Üngüren, 2011: 49). Cloninger (1987: 574) çalışmasının erken dönemlerinde sadece yenilik arayışı, zarardan kaçınma ve ödül bağımlığını mizacın üç faktörü olarak tanımlamıştır. Sebat etme çalışmaların ilerleyen aşamalarında dördüncü mizaç boyutu olarak dahil edilmiştir.

Karakterin boyutları ise sırasıyla; kendini yönetme, iş birliği, kendini aşma (Cloninger vd., 1993: 978) olarak ifade edilmektedir. Bu boyutlardan kendini yönetme, bireyin kendini özerk bir birey olarak tanımlamasını; işbirliği, insanlığın bütünleşik bir parçası olmasını ve kendini aşma, bütün evrenin ayrılmaz bir parçası olarak algıladığı boyutları ifade etmektedir.

Psikobiyolojik kuram kapsamında kişiliğin bileşenleri olan karakter ve mizacın faktör ve alt faktörleri Tablo 1'de görülmektedir.

Tablo 1. Karakter ve Mizacın Faktör ve Alt Faktörleri

\begin{tabular}{ll}
\hline \multicolumn{1}{c}{ Mizaç Faktörleri } & \multicolumn{1}{c}{ Karakter Faktörleri } \\
\hline 1. Yenilik Arayışı & 1. Kendi Kendini Yönetme \\
1.1. Keşfetmekten heyecan duyma & 1.1. Sorumluluk alma \\
1.2. Dürtüsellik & 1.2. Amaçlılık \\
1.3. Savurganlık & 1.3. Beceriklilik \\
1.4. Düzenlilik & 1.4. Kendini kabullenme \\
& 1.5. Aydınlanmış ikinci mizaç \\
\hline
\end{tabular}

\section{Zarardan Kaçınma}

2.1. Beklenti endişesi ve karamsarlık

2.2. Belirsizlik korkusu

2.3. Yabancılardan çekinme

2.4. Çabuk yorulma ve dermansızlık
2. İş Birliği Yapma

2.1. Sosyal kabullenme

2.2. Empati duyma

2.3. Yardımseverlik

2.4. Acıma

2.5. Temiz kalplilik vicdanlılık

\section{3. Ödül Bağımlılığı}

3.1. Duygusallık

3.2. Bağlanma

3.3. Bağımlılık
3. Kendi Kendini Aşma

3.1. Kendini kaybetme

3.2. Kişiler arası özdeşim

3.3. Manevi kabullenme

\section{Sebat Etme}

Verilerin dağılımları incelendiğinde, TCI ölçeğindeki temiz kalplilik (K_IB_TMZKALP) faktörünün basıklık (kurtosis) değerinin 3,786; etik eğilimler ölçeğindeki 9. madde (kurtosis: 3,928), 11. madde (kurtosis: 3,561), 14. madde (kurtosis: 1,891), 16. madde (kurtosis: 3,784), 17. madde (kurtosis: 3,033), 19. madde (kurtosis: 3,282), 20. madde (kurtosis: 1,571), 22. madde (kurtosis: 2,630), 24. madde (kurtosis: 2,546) ve 25. madde (kurtosis: 4,855), kurtosis değerleri göz önünde bulundurularak normal dağılıma uygun olmadığı, diğer verilerin basıklık ve çarpıklık değerlerinin $+1,500$ ve $-1,500$ arasında olduğu görülmüştür (Ek-1). Tabashnick ve Fidell (2013), $+1,500$ ve $-1,500$ arasındaki çarpıklık ve basıklık değerlerine sahip verilerin dağılımının normal dağılım olarak gerçekleştiğini kabul etmektedir. Çalışma kapsamında parametrik analizlerin yapılabilmesi amacıyla normal dağılımına uygun olmayan veriler analiz sürecine dahil edilmeyecektir.

TCI ölçeğinin 2004 yılında yapılan Türkçe uyarlamasına ilişkin geçerlilik ve güvenirlik çalışmasında ölçeğin Cronbach's Alpha değerleri mizaç boyutunda .60 ile .85 , karakter boyutunda .82 ile .83 arasında bulunmuştur 
A. Doğan - T. Arar - M. Öneren - C. Kartal 11/3 (2019) 2273-2289

(Köse vd., 2004: 112). Benzer şekilde Arkar vd. (2005: 195-196) tarafından yapılan analiz sonuçlarına göre TCI ölçeklerinin Cronbach's Alpha değerleri, mizaç ölçeklerinde 0.55 ile 0.84, ve karakter ölçeklerinde 0.80 ile 0.84 arasında tespit edilmiştir. Yapılan çalışmalar sonucunda Mizaç ve Karakter Envanterinin Türkçe formunun tatmin edici psikometrik özelliklere sahip olarak doğrulandığı, Mizaç ve Karakter Envanterinin hem klinik uygulamalarda hem de diğer araştırmalarda kişiliği değerlendirmek için kullanılabilecek bir araç olduğu (Arkar vd., 2005: 203) ifade edilmiştir. Bu çalı̧̧mada toplanan verilerin güvenilirliklerinin SPSS programı aracılığ 1 ile analiz edilmesi sonucunda Cronbach's Alpha değerleri, mizaç boyutlarında yenilik arayışı faktörü için $\alpha=.741$; zarardan kaçınma $\alpha=.830$; ödül bağımlılığ $\alpha=.612$; sebat etme $\alpha=.635$ olarak tespit edilmiştir. Karakter boyutlarının Cronbach's Alpha değerleri ise kendini yönetme $\alpha=.813$; işbirliği yapma $\alpha=.765$ ve kendini aşma $\alpha=.803$ olarak bulunmuştur. Bu değerler daha önceki çalışmalarda bulunan Cronbach's Alpha değerleri ile tutarlılık göstermektedir.

Ölçeğin faktör yapısı Köse vd.'nin (2004: 113) çalışmalarında olduğu gibi Mizaç ve Karakter faktörleri ayrı ayrı faktör analiziyle incelenmiştir. Değişkenler arasındaki korelasyonlar göz önünde bulundurularak faktör analizinde Türkçe uyarmada olduğu gibi oblimin dönüşüm metodu tercih edilmiştir. Çalışmada mizaç faktörü ile ilgili veriler için yapılan Kaiser-Meyer-Olkin (KMO) analizi 0,706 düzeyinde bulunmuştur. KMO değerinin 1'e yaklaştıkça mükemmel, 0,50'nin altında ise kabul edilemez olduğu belirtilmektedir 0,706>0,5 olması kullanılan verilerin faktör analizine uygunluğunu ifade etmektedir (Saruhan ve Özdemirci, 2016: 225). Buna göre ölçekte 4 faktörden oluşan mizaç boyutuna ilişkin faktör yapısının bu çalışmada Tablo 2'de görüldüğü üzere 3 faktörlü bir yapıda olduğu tespit edilmiştir.

Tablo 2' de görülen yeni bileşen yapısının Köse vd, (2004) tarafından yapılan isimlendirmeye uygun olarak, 1. Bileşeni: Zarardan kaçınma, 2. Bileşeni: Yenilik arayışı ve Sebat etme, 3. Bileşeni: Ödül bağımlılığı olarak isimlendirmek mümkündür.

Tablo 2 incelendiğinde ;

- Ödül bağımlılığı faktörü ölçeğin orijinal halinde olduğu gibi tek bir faktör altında toplandığı,

- $\quad$ Köse vd. (2004) tarafından yapılan çalışmada ayrı bir mizaç faktörü olan sebat etmenin, yenilik arayışı faktörünün altında yer aldığı,

- $\quad$ Zarardan kaçınma mizaç faktörünün tüm alt faktörlerinin aynı faktör grubu içinde olduğu ancak ölçeğin orijinal yapısında "yenilik arayışı" faktörü içinde yer alan 'keşfetmekten heyecan duyma'nın da zarardan kaçınma faktör grubu içinde yer aldığı görülmektedir.

Tablo 2. Mizaç Boyutu Faktör Yapısı

\begin{tabular}{|c|c|c|c|c|}
\hline \multirow{2}{*}{ Bileşen İsimleri } & \multirow{2}{*}{ Açıklama } & \multicolumn{3}{|c|}{ Bileşenler } \\
\hline & & 1 & 2 & 3 \\
\hline M_ZK_YBNC & Yabancılardan çekinme & 778 & & \\
\hline M_ZK_BLRSZLK & Belirsizlik korkusu & ,777 & & \\
\hline M_YA_KSFH & Keşfetmekten heyecan duyma &,- 746 & & \\
\hline M_ZK_B_BKLNT & Beklenti endişesi ve karamsarlık & 655 & & \\
\hline M_ZK_DRMNSZLK & Çabuk yorulma ve dermansızlık & 618 & & \\
\hline M_YA_DZN & Düzenlilik & & 769 & \\
\hline M_SE & Sebat etme & &,- 738 & \\
\hline M_YA_DRT & Dürtüsellik & & 711 & \\
\hline M_YA_SVRG & Savurganlık & & 663 & \\
\hline M_OB_BGLNM & Bağlanma & & & ,707 \\
\hline M_OB_BGMLLK & Bağımlılık & & & ,706 \\
\hline M_OB_DYGSL & Duygusallık & & & 681 \\
\hline
\end{tabular}

Karakter boyutu ile ilgili verilerle yapılan analizde Kaiser-Meyer-Olkin (KMO) 0,701 düzeyinde olup bulunan faktör yapısı Tablo 3'de görülmektedir. Buna göre orijinal ölçekte 3 bileşenden oluşan karakter boyutu bu çalışmada 4 bileşenli olarak tespit edilmiştir. 
A. Doğan - T. Arar - M. Öneren - C. Kartal 11/3 (2019) 2273-2289

Tablo 3. Karakter Boyutu Faktör Yapısı

\begin{tabular}{|c|c|c|c|c|c|}
\hline \multirow{2}{*}{ Bileşen İsimleri } & \multirow{2}{*}{ Açıklama } & \multicolumn{4}{|c|}{ Bileşenler } \\
\hline & & 1 & 2 & 3 & 4 \\
\hline$\overline{\text { K_KY_BCRKL }}$ & Beceriklilik & 805 & & & \\
\hline K_KY_AMACL & Amaçlılık & ,769 & & & \\
\hline K_KY_AYDNMZC & Aydınlanmış ikinci mizaç & ,716 & & & \\
\hline K_KY_SA & Sorumluluk alma & 674 & & & \\
\hline K_KA_KNDNKYBT & Kendini kaybetme & & ,777 & & \\
\hline K_KA_MNVKBL & Manevi kabullenme & & 769 & & \\
\hline K_KA_KOZDESM & Kişiler arası özdeşim & & 671 & & \\
\hline K_KY_KNDNIKBL & Kendini kabullenme & &,- 531 & & \\
\hline K_IB_YRDIMSVR & Yardımseverlik & & &,- 902 & \\
\hline K_IB_EMPATI & Empati duyma & & &,- 678 & \\
\hline K_IB_ACIMA & Acıma & & & &,- 819 \\
\hline K_IB_SSYLKBL & Sosyal kabullenme & & & &,- 735 \\
\hline
\end{tabular}

Tablo 3'te görülen yeni bileşen yapısının Köse vd. (2004) tarafından yapılan isimlendirmeye benzer olarak, 1. Bileşeni: Kendini yönetme, 2. Bileşeni: Kendini aşma, 3. Bileşeni: İş birliği, 4. Acıma olarak isimlendirmek mümkündür. Yapılan faktör analizine göre ölçekteki kişilik özelliklerinin dağılımı Tablo 4'te görülmektedir.

Tablo 4. Mizaç ve Karakterin Düzenlenmiş Dağılımı

\begin{tabular}{ll}
\hline \multicolumn{1}{c}{ Mizaç Faktörleri } & \multicolumn{1}{c}{ Karakter Faktörleri } \\
\hline 1. Zarardan Kaçınma & 1. Kendi Yönetme \\
Yabancılardan çekinme & Beceriklilik \\
Belirsizlik korkusu & Amaçlılık \\
Keşfetmekten heyecan duyma & Aydınlanmış ikinci mizaç \\
Beklenti endişesi ve karamsarlık & Sorumluluk alma \\
Çabuk yorulma ve dermansızlık & \\
\hline 2. Yenilik Arayışı & 2. Kendini Aşma \\
Dürtüsellik & Kendini kaybetme \\
Savurganlık & Manevi kabullenme \\
Düzenlilik & Kişiler arası özdeşim \\
Sebat etme & Kendini kabullenme \\
\hline 3. Ödül Bağımlılığı & 3. İş Birliği \\
Duygusallık & Yardımseverlik \\
Bağlanma & Empati duyma \\
Bağımlılık & 4. Acıma \\
& Acıma \\
& Sosyal kabullenme \\
\hline
\end{tabular}

Etik Eğilimler ölçeği, Karadağ ve Koçyiğit (2017) tarafından etik teorilerine dayalı olarak geliştirilen 26 sorudan oluşan ölçekte eğilimler; teleolojik etik, deontolojik etik, erdem etiği olarak 3 grupta incelenmiştir. Ölçeğin güvenirliğinin sınanması amacıyla yapılan çalışmada her faktörün Alpha, Guttman, Yarıya Bölme (YB) ve Test-Tekrar-Test (TTT) güvenirlik katsayısı hesaplanmış ve teleolojik etik faktöründe $\alpha=.74$, Guttman $=.75, \mathrm{YB}=.76, \mathrm{TTT}=.93$; deontolojik etik faktöründe $\alpha=.67$, Guttman $=.70, \mathrm{YB}=.74, \mathrm{TTT}=.91$ ve erdem etiği faktöründe $\alpha=.73$, Guttman $=.71, \mathrm{YB}=.75, \mathrm{TTT}=.90$ bulunmuştur (Koçyiğit ve Karadağ, 2017: 293). Bu çalışmada etik eğilimler ölçeği ile elde edilen veriler incelendiğinde teleolojik etik faktöründe $\alpha=.710$; deontolojik etik faktöründe $\alpha=.688$; erdem etiği faktöründe $\alpha=.778$ olarak bulunmuştur.

Etik eğilimler ölçeğinin faktör analizi yapıldığında, normal dağılıma uygun olmaması, faktör yükünün $0,40^{\prime} ı n$ altında olması ve binişik madde sorunları nedeniyle, ölçekte yer alan 9, 11, 12, 14, 16, 17, 19, 20, 22, 24, 25 ve 26. maddeler çıkarılarak yeniden bileşen analizi yapılmıştır. Buna göre KMO değeri .721 olarak bulunan analize ilişkin dağılım, Tablo 5'te görülmektedir. 
A. Doğan - T. Arar - M. Öneren - C. Kartal 11/3 (2019) 2273-2289

Orijinal ölçeğin üç bileşenli olan yapısı bu çalışmada dört bileşen olarak tespit edilmiştir. Tablo 5 'te yer alan veriler göz önünde bulundurularak 1. bileşen 'teleolojik (amaççı) etik eğilimi', 2. bileşen 'erdem ve yükümlülük (deontolojik) etik eğilimi', 3. bileşen 'acıdan kaçınma eğilimi ve 4 . bileşen 'durumsal teleolojik etik eğilimi’ olarak orijinal ölçekten farklı şekilde isimlendirilmiştir.

Tablo 5. Etik Eğilimler Faktör Yapısı

\begin{tabular}{lcccc}
\hline $\begin{array}{c}\text { Ölçek Madde } \\
\text { No }\end{array}$ & $\begin{array}{c}\text { 1- Teleolojik } \\
\text { Etik E. }\end{array}$ & $\begin{array}{c}\text { 2- Erdem ve Yük. } \\
\text { Etik E. }\end{array}$ & $\begin{array}{c}\text { Bileșenler } \\
\text { 3- Acidan Kaçınma } \\
\text { Eğilimi }\end{array}$ & $\begin{array}{c}\text { 4- Durumsal Teleolojik } \\
\text { Etik E. }\end{array}$ \\
\hline 8. madde &, 712 & & & \\
6. madde &, 700 & & & \\
2. madde &, 673 & & & \\
7. madde &, 666 & & & \\
1. madde &, 504 &, 747 & &, 740 \\
13. madde & &, 683 & & \\
23. madde & &, 646 & & \\
21. madde & & & & \\
15. madde & & & & \\
10. madde & & & & \\
3. madde & & & & \\
4. madde & & & & \\
5. madde & & & & \\
\hline
\end{tabular}

Çalışanların performans değerlendirme sonuçları tespit edilirken, işletmeler tarafından uygulanan performans değerlendirme sistemleri incelenmiş, her işletmenin performans sonucuna göre prim ödemesi yaptığı, çalışanın eğitim ve gelişim uygulamalarına karar verdiği sonuç puanları esas alınmıştır. Farklı işletmeler tarafından kullanılan puanlama sistemleri onluk puanlama sistemine çevrilerek analizler yapılmıştır.

\section{4. Örneklem}

Araştırmaya Ankara ilinde bulunan uluslararası düzeyde faaliyet gösteren tıbbi cihaz üretim fabrikası, ulusal düzeyde elektrik ürünleri üretim fabrikası, ulusal ve uluslararası düzeyde faaliyet gösteren mühendislik firması ve hizmet sektöründe faaliyet gösteren finansal danışmanlık firması olmak üzere 4 firmanın çalışanları dahil edilmiştir. Söz konusu firmalardaki çalışanlara toplam 180 adet TCI ölçeği ve Etik Eğilimler ölçeği basılı olarak teslim edilmiş ancak 114 çalışandan geri bildirim alınabilmiştir. Buna göre çalışmaya geri dönüş yapan çalışan oranı \%63'tür.

\subsection{Verilerin Analizi}

TCI ölçeği, etik eğilimler ölçeği ile katılımcılardan alınan veriler ve işletme insan kaynakları uygulayıcılarından alınan performans değerlendirme sonuçlarının analizi için önce IBM SPSS Statistic 22 programına veri girişi yapılmıştır. Veri girişlerinin tamamlanmasının ardından araştırmanın amaçları doğrultusunda SPSS 22 programında korelasyon analizleri, AMOS 24 programında ise model uygunluğunun analizi yapılmıştır.

\section{BULGULAR}

Araştırma örneklemi kapsamındaki 114 katılımcıdan 3'ünün performans bilgisi olmadığından analize dahil edilmemiştir. 111 katılımcının 69'u (\%62,2) erkek, 42'si (\%37,8) kadın olup, katılımcıların 33'ü $(\% 29,7)$ idari personel, 14'ü $(\% 12,6)$ mühendis, 30'u (\%27) işçi, 17'si $(\% 15,3)$ pazarlama ve satış personeli ve $15^{\prime} \mathrm{i}(\% 13,5)$ de tekniker olarak görev yapmaktadır. $2(\% 1,8)$ katılımcı, görev bilgisini belirtmemiştir.

H1: Mizaç faktörleri ve iş performansı arasında anlamlı bir ilişki vardır.

Faktör yapısı itibariyle bakıldığında Tablo 6 ' da görüleceği üzere yenilik arayışı ve sebat faktörü ile performans arasında $(r=, 224)$ anlamlı ve pozitif yönlü ilişki vardır.

Tablo 6. Mizaç Faktörleri ve İş Performansı Arasındaki İlişki 
A. Doğan - T. Arar - M. Öneren - C. Kartal 11/3 (2019) 2273-2289

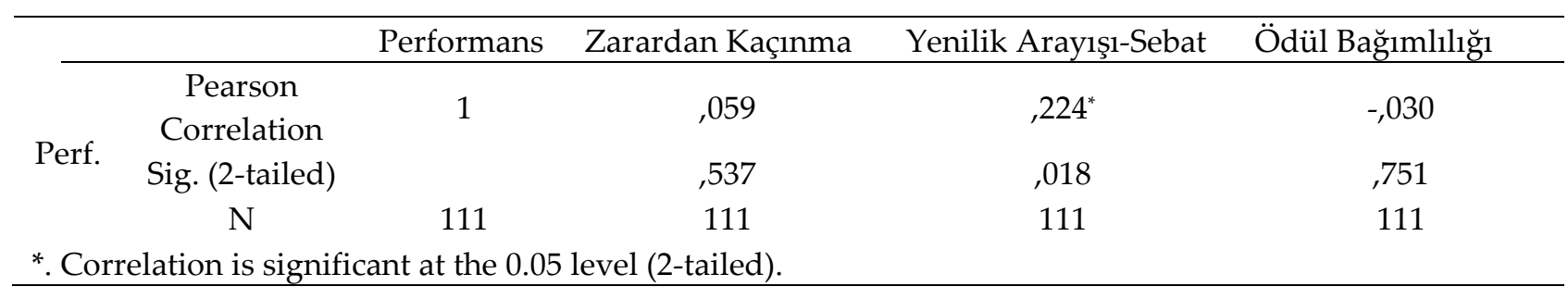

Çalışmada belirlenen haliyle alt faktörlerinin toplamı olarak mizaç ile iş performansı arasındaki ilişki incelendiğinde Tablo 7'de görüldüğü üzere iş performansı ve mizaç arasında anlamlı bir korelasyon tespit edilememiştir.

Tablo 7. Mizaç ve İş Performansı Arasındaki İlişki

\begin{tabular}{cccc}
\hline & & Performans & Mizac \\
\hline \multirow{2}{*}{ Perf. } & Pearson Correlation & 1 &, 139 \\
& Sig. (2-tailed) & &, 144 \\
& $\mathrm{~N}$ & 111 & 111 \\
\hline
\end{tabular}

H2: Karakter faktörleri ile iş performansı arasında anlamlı bir ilişki vardır.

Karakter faktörleri ile performans sonucu arasında korelasyonları gösteren Tablo 8'den de anlaşılacağı üzere, acıma alt faktörü iş performansı arasında anlamlı ve negatif yönlü bir ilişki tespit edilmiştir $(\mathrm{r}=-, 198)$.

Tablo 8:Karakter Faktörleri ve İş Performansı Arasındaki İlişki

\begin{tabular}{cccccc}
\hline & & KendiniYönetmek & KendiniAsma & Isbirligi & Acıma \\
\hline \multirow{2}{*}{ Perf. } & Pearson Correlation &,- 014 &,- 065 &, 051 &, $192^{*}$ \\
& Sig. (2-tailed) &, 884 &, 495 &, 593 &, 044 \\
& $\mathrm{~N}$ & 111 & 111 & 111 & 111 \\
\hline
\end{tabular}

Karakter ve iş performansı arasındaki ilişki incelendiğinde ise Tablo 9 da görüldüğü üzere iş performansı ve mizaç arasında anlamlı bir korelasyon tespit edilememiştir.

Tablo 9. Karakter ve İş Performansı Arasındaki İlişki

\begin{tabular}{lccc}
\hline & & Performans & Karakter \\
\hline & Pearson Correlation & 1 &, 096 \\
Perf. & Sig. (2-tailed) & &, 316 \\
& $\mathrm{~N}$ & 111 & 111 \\
\hline
\end{tabular}

H3: Karakter faktörleri ile etik eğilimleri arasında anlamlı bir ilişki vardır.

Karakter ve etik eğilim arasındaki ilişki incelendiğinde, Tablo $10^{\prime}$ da görüleceği üzere iki faktör arasında korelasyon bulunmamaktadır.

Tablo 10. Etik Eğilim ve Karakter Arasındaki İlişki

\begin{tabular}{|c|c|c|c|c|}
\hline & & Etik & & \\
\hline \multirow{3}{*}{ Etik } & Pearson Correlation & & 1 & ,099 \\
\hline & Sig. (2-tailed) & & & ,300 \\
\hline & $\mathrm{N}$ & & 111 & 111 \\
\hline
\end{tabular}

Ancak karakter ve etik eğilimlerin alt faktörleri arasında ilişkiler incelendiğinde Tablo 11'de görüleceği üzere kendini aşma, iş birliği ve acıma faktörlerinin en az bir etik faktörü ile anlamlı pozitif ya da negatif yönlü ilişkili olduğu görülmektedir. Kendini aşma faktörü ile teleolojik etik eğilimi $(r=, 263)$ arasında anlamlı ve pozitif yönlü; işbirliği faktörü ile acıdan kaçınma eğilimi $(\mathrm{r}=, 248)$ arasında anlamlı ve pozitif yönlü, erdem ve yükümlülük etik eğilimi ( $(\mathrm{r}=-, 275)$ arasında anlamlı ve negatif yönlü; acıma faktörü ile durumsal teleolojik etik eğilimi $(\mathrm{r}=, 187)$ arasında anlamlı ve pozitif yönlü, teleolojik etik eğilimi $(\mathrm{r}=-, 215)$ arasında anlamlı negatif yönlü ilişki vardır. 
A. Doğan - T. Arar - M. Öneren - C. Kartal 11/3 (2019) 2273-2289

Tablo 11. Etik Eğilimler ve Karakter Faktörleri Arasındaki İlişki

\begin{tabular}{llrrrr}
\hline & & Kendini Yönetmek & Kendini Asma & İş birliği & \multicolumn{2}{c}{ Acıma } \\
\hline \multirow{2}{*}{ Teleolojik Etik } & Pearson Correlation &,- 114 &, $263^{* * *}$ &, 047 &,$- 215^{*}$ \\
& Sig. (2-tailed) &, 233 &, 005 &, 627 &, 024 \\
& $\mathrm{~N}$ & 111 & 111 & 111 & 111 \\
\hline \multirow{2}{*}{ Erdem ve } & Pearson Correlation &, 119 &, 083 &,$- 215^{*}$ &,- 105 \\
Yükümlülük Etik & Sig. (2-tailed) &, 213 &, 387 &, 023 &, 274 \\
& $\mathrm{~N}$ & 111 & 111 & 111 & 111 \\
\hline \multirow{2}{*}{ Acıdan Kaçınma } & Pearson Correlation &,- 094 &, 177 &, $248^{* *}$ &, 054 \\
Eğilimi & Sig. (2-tailed) &, 325 &, 064 &, 009 &, 570 \\
& $\mathrm{~N}$ & 111 & 111 & 111 & 111 \\
\hline \multirow{2}{*}{ Durumsal } & Pearson Correlation &,- 059 &,- 081 &, 042 &, $187^{*}$ \\
Teleolojik Etik & Sig. (2-tailed) &, 541 &, 398 &, 662 &, 049 \\
& $\mathrm{~N}$ & 111 & 111 & 111 & 111 \\
\hline
\end{tabular}

H4: Mizaç faktörleri ile etik eğilimleri arasında anlamlı bir ilişki vardır.

Tablo 12' de görüleceği üzere mizaç ve etik eğilim arasındaki korelasyon bulunmamaktadır.

Tablo 12. Mizaç ve Etik Eğilim Arasındaki İlişki

\begin{tabular}{lccc}
\hline & & Etik & Mizaç \\
\hline \multirow{3}{*}{ Mizaç } & Pearson Correlation &, 004 & 1 \\
& Sig. (2-tailed) &, 964 & \\
& $\mathrm{~N}$ & 111 & 111 \\
\hline
\end{tabular}

Etik eğilimler ve mizaç alt faktörleri arasındaki ilişkiler incelendiğinde, Tablo 13'de görüldüğü üzere, zarardan kaçınma faktörüyle hiçbir etik eğilimi arasında anlamlı bir ilişki bulunamamıştır.

Tablo 13 . Etik Eğilimler ve Mizaç Faktörleri Arasındaki İlişki

\begin{tabular}{lcccc}
\hline & & Zarardan Kaçınma & Yenilik Arayışı Sebat & Ödül Bağımlılı̆̆ \\
\hline \multirow{4}{*}{ Teleolojik Etik } & Pearson Correlation &,- 063 &,- 168 &, 010 \\
& Sig. (2-tailed) &, 512 &, 078 &, 918 \\
& $\mathrm{~N}$ & 111 & 111 & 111 \\
\hline \multirow{2}{*}{ Erdem ve } & Pearson Correlation &,- 002 &,$- 366^{* *}$ &, 045 \\
Yükümlülük Etik & Sig. (2-tailed) &, 982 &, 000 &, 636 \\
& $\mathrm{~N}$ & 111 & 111 & 111 \\
\hline \multirow{4}{*}{ Acıdan Kaçınma } & Pearson Correlation &, 181 &, 070 &, 021 \\
& Sig. (2-tailed) &, 057 &, 463 &, 828 \\
\hline \multirow{2}{*}{ Durumsal Teleolojik } & N & 111 & 111 & 111 \\
Etik & Pearson Correlation &, 053 &, $325^{* *}$ &,- 091 \\
& Sig. (2-tailed) &, 578 &, 000 &, 342 \\
\hline
\end{tabular}

Yenilik arayışı ve sebat etme bileşeni, erdem ve yükümlülük etik eğilimi (r=,-366) ile negatif yönlü ve anlamlı, durumsal teleolojik etik eğilimi ile $(r=, 325)$ pozitif yönlü anlamlı ilişki bulunmuştur.

H5: Etik eğilimler ile iş performansı arasında anlamlı bir ilişki vardır.

Tablo 14'de görüleceği üzere genel etik eğilimi ile iş performansı arasında ilişki tespit edilmemiştir. Bununla birlikte acıdan kaçınma eğilimi ile iş performansı arasında $(r=, 208)$ pozitif yönlü ve anlamlı ilişki olduğu Tablo 15 'de görülmektedir. 
A. Doğan - T. Arar - M. Öneren - C. Kartal 11/3 (2019) 2273-2289

Tablo 14. Etik Eğilim ve İş Performansı Arasındaki İlişki

\begin{tabular}{lccc}
\hline & & Performans & Etik \\
\hline \multirow{3}{*}{ Performans } & Pearson Correlation & 1 &, 013 \\
& Sig. (2-tailed) & &, 890 \\
& $\mathrm{~N}$ & 111 & 111 \\
\hline
\end{tabular}

Tablo 15. Etik Eğilim Faktörleri ve İş Performansı Arasındaki İlişki

\begin{tabular}{ccccccc}
\hline & Performans & $\begin{array}{c}\text { Teleolojik } \\
\text { Etik }\end{array}$ & $\begin{array}{c}\text { Erdem ve } \\
\text { Yükümlülük Etik }\end{array}$ & $\begin{array}{c}\text { Acıdan } \\
\text { Kaçinma } \\
\text { Eğilimi }\end{array}$ & $\begin{array}{c}\text { Durumsal } \\
\text { Teleolojik } \\
\text { Etik }\end{array}$ \\
\hline \multirow{7}{*}{ Performans } & $\begin{array}{c}\text { Pearson } \\
\text { Correlation }\end{array}$ & 1 &,- 026 &,- 180 &, $208^{*}$ &, 025 \\
& Sig. (2-tailed) & &, 786 &, 059 &, 029 &, 796 \\
$\mathrm{~N}$ & 111 & 111 & 111 & 111 & 111 \\
\hline
\end{tabular}

H6: Kişilik özellikleri ile iş performansı arasındaki ilişkide etik değerlerin aracılık rolü bulunmaktadır.

Araştırma hipotezlerine uygun olarak oluşturulan modelin geçerliliğini tespit edebilmek amaciyla AMOS 24 programında Şekil 2' de görülen model kurulmuştur. Buna göre model uyum değerleri incelendiğinde RMSEA $=0.076, \mathrm{NFI}=0.599, \mathrm{CFI}=.767$ olarak bulunmuştur. Bir faktörün yeterince güvenilir olduğunu ifade edebilmek için, RMSEA<0,10; SRMR<0,10; CFI>0,90; NFI>0,90 değerleri sağlanmalıdır (Saruhan ve Özdemirci, 2016: 295).

Araştırma verileri ile ulaşılan sonuçlara göre, araştırma modelinin doğrulanmadığı görülmüş olup, bu çalışma kapsamında kişilik faktörlerinin iş performansına etkisinde etik eğilimlerin aracılık etkisinden söz etmek mümkün olmamaktadır.

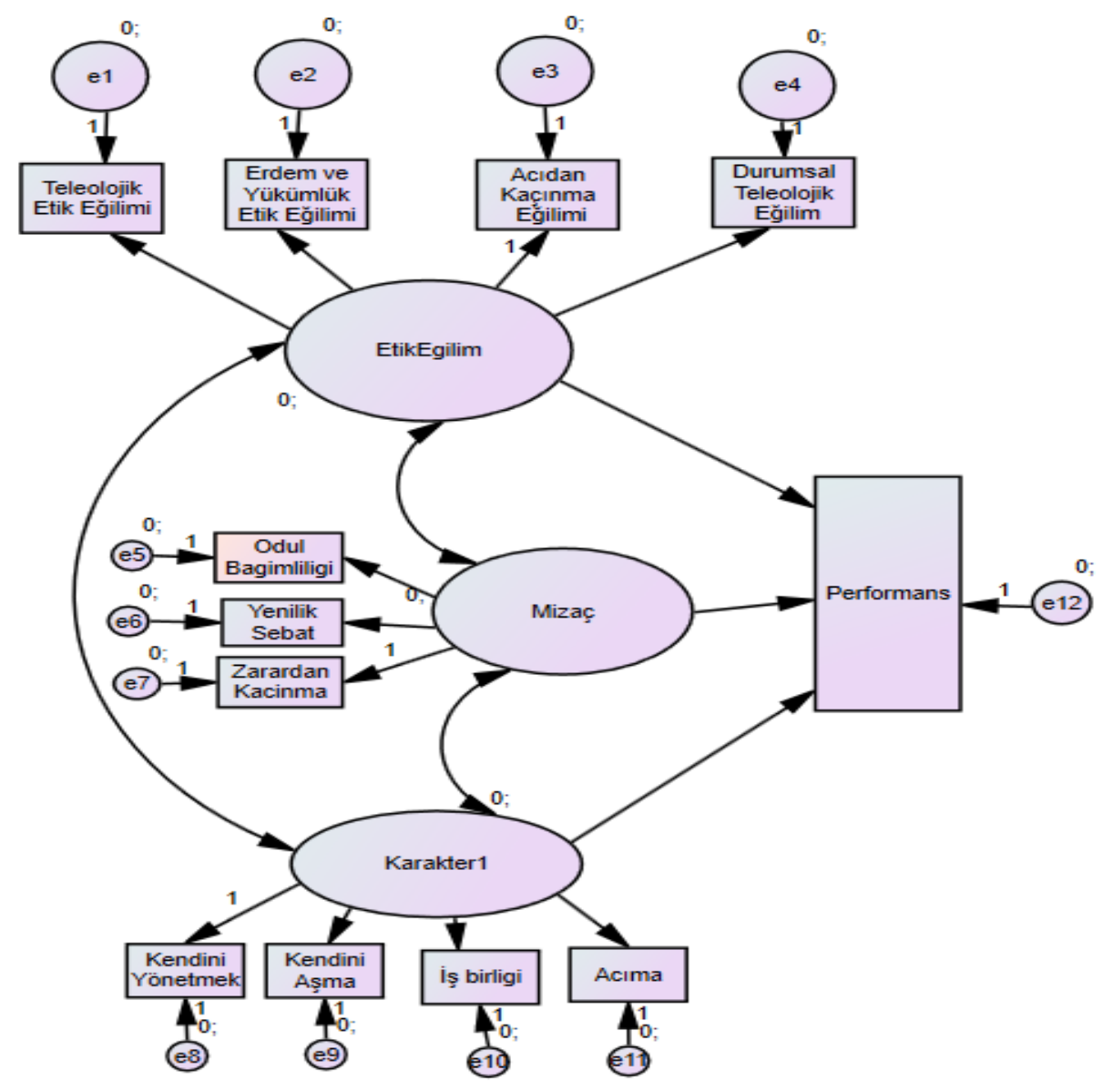

Şekil 2. Kişilik-Etik Eğilim ve İş Performansı İlişki Modeli 


\section{SONUÇ VE TARTIŞMA}

Psikobiyolojik kişilik kuramı kapsamında, karakter ve mizaç ile iş performansı arasındaki ilişkide etik eğilimlerinin rolünün incelendiği bu çalışmada H1(Mizaç faktörleri ve iş performansı arasında anlamlı bir ilişki vardır) ve $\mathrm{H} 2$ (Karakter faktörleri ile iş performansı arasında anlamlı bir ilişki vardır) hipotezleri karakter faktöründe 'acıma' alt faktörü, mizaç faktöründe ise 'yenilik arayışı ve sebat etme' alt faktörleriyle iş performansı arasında ilişki tespit edilebildiğinden kısmen kabul edilebilmektedir. Her ne kadar literatürde özellikle beş faktör kişilik özelliklerinin iş performansını yordayıcı özelliğe sahip olduğuna (Yelboğa, 2006: 292) ve TCI ölçeği ile beş faktör kişilik envanteri arasında anlamlı korelasyon olduğuna (De Fruyt vd. 2000: 441) yönelik çalışmalar olsa da bu çalışmada TCI ölçeği ile elde edilen verilerin iş performansını yordama konusunda aynı yeterliliğe sahip olmadığı görülmektedir.

Sonuçlardaki bu farklılığın nedenlerinden birisinin, katılımcıların kişilik değerlendirmelerinin öz bildirim yoluyla, performans değerlendirmelerinin ise yöneticilerinin bildirimiyle yapılmış olması, ayrıca performans değerlendirmesi yapan kişilerin de birden çok kişi olması, işletmeler bazında kullanılan farklı performans değerlendirme sistemlerinin olması olarak ifade edilebilir. Ayrıca bu çalışmada veri olarak kullanılan işletmelerin performans ölçümleri sonuçlarında, bağlam performansı ile görev performansı değerlendirmelerine ilişkin dağılımlar tespit edilemediğinden karakter ve mizacın söz konusu performans boyutları arasındaki ilişkiyi incelemek mümkün olmamıştır. İleriki çalışmalarda kişilik özelliklerinin performansın farklı boyutları ile ilişkinin incelenmesinin konuya farklı perspektifler kazandıracağı düşünülmektedir.

Araştırmanın H3 (Karakter faktörleri ile etik eğilimleri arasında anlamlı bir ilişki vardır) hipotezi 'acıma' faktörünün 'teleolojik etik' ve 'durumsal teleolojik etik eğilimi' ile 'iş birliği' faktörünün 'erdem ve yükümlülük etik eğilimi' ve 'acıdan kaçınma eğilimi' ile son olarak da 'kendini aşma' faktörünün 'teleolojik etik eğilimi' ile ilişkili olması nedeniyle kısmen kabul edilebilmektedir. Benzer şekilde H4 (Mizaç faktörleri ile etik eğilimleri arasında anlamlı bir ilişki vardır) hipotezi mizaç faktörlerinden 'yenilik arayışı' faktörünün 'durumsal teleolojik etik eğilimi' ve 'erdem-yükümlülük etik eğilimleri' ile ilişkili olması nedeniyle kısmen kabul edilebilmektedir. Mizaç faktöründe sadece bir alt faktörün, karakter faktöründe ise üç alt faktörün farklı etik eğilimlerle ilişkili olması, psikobiyolojik kişilik kuramının mizacın kültürel etkiler karşısında değişmez olduğu karakterin ise sosyo-kültürel öğrenmeyle vücut bulan yapısı olduğu varsayımı ile uyum göstermektedir.

H5 (Etik eğilimler ile iş performansı arasında anlamlı bir ilişki vardır) hipotezi 'acıdan kaçınma eğilimi' alt faktörü ve iş performansı arasındaki ilişki göz önünde bulundurulduğunda kısmen kabul edilebilmektedir. Bu durum Protestan etiği, İslami iş etiği gibi etik yaklaşımları ile iş performansı arasındaki ilişki tespit eden çalışmalarla çelişiyor gibi görünmekle birlikte bu farklılığın söz konusu etik modellerin davranışa yönelik daha somut yaklaşımlarının olması, etik eğilimlerin ise daha soyut düzlemde kalması nedeniyle işe yönelik tutum ve davranışları yordama konusunda daha az etkili olduğu şeklinde yorumlanabilir.

Araştırma kapsamında yapılan analizler sonucunda H6 (Kişilik özellikleri ile iş performansı arasındaki ilişkide etik değerlerin aracılık rolü bulunmaktadır) hipotezi kabul edilememiştir. Bu durum kişi iş uyumunun iş tatmini ile (.56) örgütsel bağlllık ile (.47) ve işten ayrılmaya eğilim ile (-.46), iş arkadaşlarından tatmin (.32) amirinden tatmin (.33) ve genel performans (.20) ile ilişki bulgulayan çalışmalar (Aktaş 2011, 15) 1şığında değerlendirildiğinde, kişiliğin ve etik eğilimlerin iş performansından çok, örgütsel bağlllık, iş tatmini, işten ayrılmaya eğilim, iş arkadaşından tatmin gibi iş tutumlarıyla daha yüksek düzeyde ilişkisinin olabileceği şeklinde yorumlanabilir. Bütün bunlara ilave olarak H1, H2 ve H3 hipotezlerinin kismen kabul edilmesinden de anlaşılacağı üzere kişiliğin bütün özelliklerinin iş performansına etki etmesindense, kişiliğin farklı boyutlarının iş performansının ve örgütsel tutumların farklı boyutları ile ilişkili olabileceği düşünülebilir. İleride yapılacak araştırmalarda bu kapsamda gerek iş performansı gerekse kişiliğin ve etik anlayışının farklı boyutları arasındaki ilişkilerin incelenmesi faydalı olacaktır.

Araştırma sonuçları göz önünde bulundurulduğunda özellikle uygulamada yaygın olan belirli kişilik özelliklerine sahip adayların daha başarılı olacağına ilişkin algının tersine, kişilik özellikleri ve etik eğilimlerin yerine daha somut düzeyde tutum ve davranışları belirlemeye yönelik yöntemlere odaklanılmasının çalışanların iş performansını yordamak konusunda daha etkili sonuçlar verip vermeyeceğinin araştırmaya değer bir konu olduğu öngörülmektedir. Söz konusu çalışmalar sayesinde tutum ve davranışı tespit etme 
A. Doğan - T. Arar - M. Öneren - C. Kartal 11/3 (2019) 2273-2289

metodolojisiyle kişilik ve etik eğilimleri ölçüm tekniklerinin iş performansını yordama konusundaki etkililiklerinin kıyaslanması mümkün olabileceği, böylece hem uygulama hem de teorik açıdan alana önemli katkılar sunulabileceği düşünülmektedir.

\section{KAYNAKÇA}

Akarsu, Bedia. Max Scheler Felsefesinde Kişi Kavramı ve İnsan Olma Sorunu. İstanbul: İnkılap Kitabevi, 1998.

Alakavuklar, Ozan, ve Yasemin Arbak. «Ahlaki ikilem çatışmalarının yönetiminde etik eğilimlerin rolü.» 16. Ulusal Yönetim ve Organizasyon Kongresi. Antalya, 2008. 701-704.

Anwar, Sadia, ve Naimatullah Shah. «Impact Of Personality Traits On Ethical Behavior.» The Government: Research Journal of Political Science VI (2018): 95-114.

Arkar, Haluk. «Cloninger'in Mizaç ve Karakter Boyutları ile Kişilik Bozuklukları Arasındaki İlişki.» Klinik Psikiyatri , 11 2008: 115-124.

Arkar, Haluk, ve diğerleri. «Mizaç ve Karakter Envanteri'nin Türkçe Formunun Faktör Yapısı, Geçerlik ve Güvenilirliği.» Türk Psikiyatri Dergisi, no. 16 (2005): 190-204.

Aykaç, Burhan. İnsan Kaynakları Yönetimi ve İnsan Kaynaklarının Stratejik Planlaması. Ankara: Nobel Yayın Dağıtım, 1999.

Barrick, Murray R., Michael K. Mount, ve Timothy A. Judge. «Personality and Performance at the Beginning of the New Millenium: What Do We Know and Where Do We Go Next?» International Journal of Selection and Assessment, 2001: 9-30.

Barutçugil, İsmet. Stratejik İnsan Kaynakları Yönetimi. İstanbul: Kariyer Yayıncllık, 2004.

Befort, Nancy, ve Keith Hattrup. «Valuing Task and Contextual Performance: Experience, Job Roles, and Ratings of the Importance of Job Behaviors.» Applied H.R.M. Research, 2003: 17-32.

Callen, Michael, Saad Gulzar, Ali Hasanain, Yasir Khan, ve Arman Rezaee. «Personalities And Public Sector Performance:Evidence From A Health Experiment In Pakistan.» https://www.nber.org. April 2018. https://www.nber.org/papers/w21180 (erişildi: 05 08, 2019).

Çankır, Bilal, ve Selma Arıkan. «Examining Work Engagement and Job Satisfaction Variables in their Relations with Job Performance and Intention to Quit.» İşletme Araştırmaları Dergisi, 2019: 1133-1150.

Carroll, Archie B. «Ethics in Management.» A Companion to Business Ethics içinde, yazan Robert E. Frederick, 141-152. Oxford: Blackwell Publishers Ltd, 1999.

Chamberlin, Melissa, Daniel w. Newton, ve Jeferry A. LePine. «A Meta-analysis of Empowerment and Voice As Transmitters of High-performance Managerial Practices To Job Performance.» Journal Of Organizational Behavior, 2018: 1-18.

Cloninger, C. R., T. R. Przybeck, ve D. M. Svrakic. «A Psychological Model of Temperament and Character.» Archives of General Psychiatry, 1993: 975-990.

Cloninger, C. Robert. «A Systematic Method for Clinical Description and Classification of Personality Variants.» Arch Gen Psychiatry, 1987: 573-588.

Cloninger, C. Robert, Thomas R. Przybeck, ve DraganM. Svrakic. «The Tridimensional Personality Questionnaire: US Normative Data.» Psychological Reports, 1991: 1047-1057.

Cloninger, Susan. «Conceptual issues in personality theory.» The Cambridge Handbook of Personality Psychology içinde, yazan Philip J. Corr ve Gerald Matthews. Cambridge: Cambridge University Press, 2009.

Cohen, Ronald Jay, ve Mark E Swerdlik. Psikolojik Test ve Değerlendirme. Çeviren Ezel Tavşancıl. Ankara: Nobel, 2015.

De Fruyt, F, L De Wiele, ve C Van Herringen. «Cloninger's Psychobiological Model of Temperament and Character and the Five-Factor Model of Personality.» Personality and Individual Differences, September 2000: 441-452.

Eysenck, H.J, ve Glenn Wilson. Kişiliğinizi Tanıyın. Çeviren Erol Erduran. İstanbul: Remzi Kitabevi, 2000.

Fromm, Eric. Kendini Savunan İnsan. Çeviren Ayda Yörükan. İnsan: Say Yayınları, 1995.

Greenberg, Jerald. «The Protestant Work Ethic and Reactions to Negative Performance Evaluations on a Laboratory Task.» Journal of Applied Psychology, 1977: 682-690. 
A. Doğan - T. Arar - M. Öneren - C. Kartal 11/3 (2019) 2273-2289

Hogan, Joyce, ve Brent Holland. «Using Theory to Evaluate Personality and Job-Performance Relations: A Socioanalytic Perspective.» Journal of Applied Psychology, 2003: 100-112.

Hui-Hua, Zhang, ve Nicola Schutte. «Personality, emotional intelligence and other-rated task performance.» Personality and Individual Differences, 2015: 298-301.

Imam, Awais, Abdus Sattar Abbasi, ve Saime Muneer. «Employee Performance From The Lens Of Islamic Work Ethics: Mediating Role Of Personality X And Y.» Sci. Int(Lahore), 2015: 415-422.

Imam, Awais, Abdus Sattar Abbasi, ve Saime Muneer. «The Impact Of Islamıc Work Ethıcs On Employee Performance: Testıng Two Models Of Personality X And Personality Y.» Sci. Int (Lahore), 2013: 611-617.

Koçyiğit, Mehmet, ve Mehmet Karadağ. «Etik Teorilerine Dayalı Bir "Etik Eğilimler Ölçeği" Geliştirme Çabası.» İ̧s Ahlakı, 2017: 283-307.

Kolçak, Menşure. Meslek Etiği. 2. Baskı. Bursa: Ekin Yayınevi, 2013.

Köroğlu, Ertuğrul, ve Sinan Bayraktar. Kişilik Bozuklukları. Ankara: HYB Basın Yayın, 2007.

Köse, Samet. «A Psychobiological Model Of Temperament And Character: TCI.» Yeni Symposium, 2003: 86-97.

Köse, Samet, ve diğerleri. «Mizaç ve Karakter Envanteri (Türkçe TCI): Geçerlik, Güvenirliği ve Faktör Yapısı.» Klinik Psikofarmakoloji Bülteni, 2004: 107-131.

Kuçuradi, Ioanna. Uludă̆ Konuşmaları. Ankara: Türkiye Felsefe Kurumu Yayınları, 2009.

MacDonald, Douglas, ve Daniel Holland. «Examination Of Relations Berween The Neo Personality InventoryRevised And The Temperament And Character Inventory.» Psychological Report, 2002: 921-930.

Marri, M.Y.K., A.M. Sadozai, H.M.F. Zaman, ve M.I. Ramay. «The Impact Of Islamic Work Etthic on Job Satisfaction and Organizational Commitment: A Study of Agricultural Sector in Pakistan.» International Journal of Bussiness and Behavioural Sciences, 2012: 32-45.

McClelland, D.C. Personality. New York: Holt-Dryden, 1951.

Mengüşoğlu, Takiyettin. İnsan Felsefesi. İstanbul: Remzi Kitabevi, 1988.

Menninger, K.A. The Human Mind. New York: Knopf, 1953.

Merrens, Matthew R., ve James B. Garrett. «The Protesntant Ethic Scale as a Predictor of Repetitive Work Performance.» Applied Psychology, 1975: 125-127.

Nelson, William A. «An Organizational Ethics Decision-Making Process.» Healtcare Executive, July-August 2005: 9-14.

Ntayi, J.M. «Work Ethic, locus of control and sales force task performance.» Journal of African Business, 2005: 155-176.

Öhman, Johan, ve Leif Östman. «Clarifying the Ethical Tendency in Education for Sustainable Development Practice.» Canadian Journal of Environmental Education, 2008: 57-72.

Osibanjo, Adewale Omotayo, James Olekan Akinbode, Hezekiah Olubusayo Falola, ve Akinrole Olumuyiwa Oludayo. «Work Ethics and Employees2 Jobe Performance.» Journal of Leadership, Accountability and Ethics, 12 2015: 107-117.

Özer, Erdal, ve Osman Nuri Özdoğan. «Personel Güçlendirmenin İşgörenlerin İş Performansına Etkisi: Afyonkarahisar Örneği.» İ̧sletme Araştırmaları Dergisi, 2019: 1205-1224.

Özkan, Osman Seray, ve Tolga Omay. «Psikolojik Sermayenin Bireysel Performans Üzerindeki Etkisinde Birey-Örgüt Uyumunun Aracılık Rolü: Vakıf Üniversitelerindeki Öğretim Üyelerine Yönelik Araştırma.» İşletme Araştırmaları Dergisi, 2019: 743-757.

Parks-Leduc, Laura, Gilad Feldman, ve Anat Bardi. «Personality Traits and Personal Values: A Meta Analysis.» Personality and Social Psychology Review, 2015: 3-29.

Raja, Usman, Gary Johns, ve Filotheos Ntalianis. «The Impact of Personality on Psychological Contracts.» The Academy of Management Journal, 2004: 350-367.

Ricther, Jörg, ve Rosina Neumann. «Personality of Students of Economics, Medicine, and Verbal Communication: Preliminary Results.» Psyxhology, 2011, 2 b.: 248-253.

Riggio, Ronald E. Introduction to Industrial / Organizational Pcychology. New Jersey: Pearson Education, Ic., 2013. 
A. Doğan - T. Arar - M. Öneren - C. Kartal 11/3 (2019) 2273-2289

Rothmann, S, ve E.P Coetzer. «The Big Five Personality Dimensions And Job Performance.» SA Journal of Industrial Psychology, 29 (2003): 68-74.

Saruhan, Şadi Can, ve Ata Özdemirci. Bilim, Felsefe, Metodoloji. İstanbul: Beta , 2016.

Scheler, Max. İnsanın Kosmostaki Yeri. Çeviren Harun Tepe. Ankara: BilgeSu Yayınları, 2015.

Şeker, Mustafa. Kişilik Özellikleri İle Örgütsel Bă̆lllık ve İşgören Performansı Arasındaki İlişkiler ve Kayseri Eğitim ve Araştırma Hastanesi'nde Bir Uygulama. Niğde: Niğde Üniversitesi Yayımlanmamış Yüksek Lisans Tezi, 2011.

Soysal, A. «Çalışma Yaşamında Kişilik Tipleri : Bir Literatür Taraması.» Çimento ve İşveren Dergisi, 2008: 4-19. Spranger, Eduard. İnsan Tipleri, Bir Kişilik Psikolojisi. Çeviren Ahmet Aydoğan. İstanbul: İz Yayıncılık, 2001.

Stajkovic, Alexander D., Albert Bandura, Edwin A Locke, Dongseop Lee, ve Kayla Sergent. «Test Of Three Conceptual Models Of İnfluence Of The Big Five Personality Traits And Self-Efficacy On Academic Performance: A Meta-Analytic Path-Analysis.» Personality and Individual Differences, 2018: 238-245.

Tabashnick, B.G., ve L.S. Fidell. Using Multivariate Statistics. Boston: Pearson, 2013.

Tett, Robert P., ve Dawn D Burnett. «A Personality Trait-Based Interactionist Model of Job Performance.» Journal of Applied Psychology, 2003: 300-317.

Türkeri, Mehmet. Etik Kuramları. Ankara: Lotus Yayınları, 2013.

Üngüren, Engin. Psikobiyolojik Kişilik Kuramı Ekseninde Yöneticilerin Kişilik Özellikleri, Karar Verme Stilleri Ve Örgütsel Sonuçlara Yansımaları. Antalya: Akdeniz Üniversitesi Yayınlanmamış Doktora Tezi, 2011.

Viswesvaran, Chockalingam, ve Deniz S. Ones. «Perspectives on Model of Performance.» International Journal of Selection And Assesment, 12 2002: 216-226.

Weiten, Wayne, Elizabet Yost Hammer, ve Dana S. Dunn. Psikoloji ve Çağdaş Yaşam. Çeviren Ebru İkiz. Ankara: Nobel Akademik Yayıncılık, 2015.

Yalçın, Mehmet Hanifi. Mizaç ve Karakter Envanteri - Gözden Geçirilmiş Formu (Türkçe TCI-R) Geçerlik, Gevenirliği ve Faktör Yapısı. Gaziantep: Hasan Kalyoncu Ünivesitesi Yayınlanmamış Yüksek Lisans Tezi, 2017.

Yelboğa, Atilla. «Kişilik Özellikleri ve İş Performansı Arasındaki İlişkinin İncelenmesi.» “İş,Güç” Endüstri İlişkileri ve İnsan Kaynakları Dergisi, Haziran 2006: 196-211. 